(c) American Dairy Science Association, 2007.

\title{
Study on the Influence of Pasture on Volatile Fraction of Ewes' Dairy Products by Solid-Phase Microextraction and Gas Chromatography-Mass Spectrometry
}

\author{
M. Povolo, ${ }^{\star 1}$ G. Contarini, ${ }^{*}$ M. Mele, $\dagger$ and P. Secchiari \\ ${ }^{*}$ CRA-Istituto Sperimentale Lattiero-Caseario, 26900 Lodi, Italy \\ †Dipartimento di Agronomia e Gestione dell'Agroecosistema, Sezione di Scienze Zootecniche Università di Pisa, 56124 Pisa, Italy
}

\begin{abstract}
The detection of markers of identification of the geographical origin of food is an attractive challenge and, as far as dairy products are concerned, this paper represents a contribution to this field. In this research the influence of feed on the volatile compound composition was investigated on milk, 2-mo-old cheese (Caciotta), and whey cheese (ricotta) obtained from the same flock of Sarda ewes, under standardized technological conditions. Three different types of pasture (mixture of $\mathrm{Lol}$ ium perenne and Trifolium squarrosum; rough pasture; Avena sativa) were studied. Solid-phase microextraction combined with gas chromatography-mass spectrometry was used and principal component analysis was applied for statistical evaluation of the data set. The volatile composition was significantly affected by the type of pasture independently of the type of cheese and the ripening period. Moreover, a marker of rough pasture, tentatively identified as (E,E)-3,7,11-trimethyl-2,4,10-dodecatriene, was detected only in milk and cheeses produced when the ewe flock grazed on that pasture.
\end{abstract}

Key words: pasture, milk and cheese, solid-phase microextraction, gas chromatography-mass spectrometry

\section{INTRODUCTION}

Over the last few years, several studies have been conducted on the detection of markers that could be used to identify the geographical origin of milk and cheese. This subject is particularly important for Protected Designation of Origin cheeses because their link with the region of origin has to be traced. Terpenes and hydrocarbons, being transferred from forages into milk and cheese, were shown to be promising tools for this purpose (Bosset et al., 1994; Viallon et al., 2000; Buchin et al., 2002). Volatile fraction analysis is one of the most

Received May 16, 2006.

Accepted October 10, 2006.

${ }^{1}$ Corresponding author: mpovolo@ilclodi.it important methods in quality evaluation of food and it was widely applied for this scope. Among the different extraction techniques, solid-phase microextraction (SPME), developed in 1990 (Arthur and Pawliszyn, 1990) to evaluate the volatile compounds from wastewaters, is a simple and effective sample preparation method that is now widely applied in food analysis (Kataoka et al., 2000). Flavor composition of dairy products has been evaluated in several studies by using different extraction techniques. Volatile compounds of milk have been studied concerning the effects of the type of feeding adopted in animal breeding (Bassette et al., 1966; Moio et al., 1996; Bendall, 2001; Bugaud et al., 2001a), heat treatment (Calvo and de la Hoz, 1992; Contarini and Povolo, 2002; Vasquez-Landaverde et al., 2005), storage conditions (Earley and Hansen, 1982; Marsili, 2000), and light exposure (Kim and Morr, 1996; Marsili, 1999). The quality of butter has been investigated by evaluating both the sulfur compounds, as affected by the type of cow feeding (Shooter et al., 1999), and the effects of the storage conditions (Christensen and Holmer, 1996; Povolo and Contarini, 2003). Volatiles of cheese have been widely analyzed to study the effects of the ripening process (Le Quéré et al., 1998; Carbonell et al., 2002), animal feeding (Buchin et al., 1999; Bugaud et al., 2001b), origin of defects (Kim et al., 2003), and influence of milk protein genetic variants (Verdier-Metz et al., 2000).

In our research the influence of 3 different types of pasture on the volatile compounds of ewe's milk and the derived 2-mo-old cheese (Caciotta) and whey cheese (ricotta) was investigated. The aim of our work was to provide a contribution to the detection of marker useful to link a dairy product to its region of origin. Analyses were made on samples for their chemical and volatile composition. Solid-phase microextraction combined with GC-MS was used and principal component analysis was applied for the statistical evaluation of the data set.

\section{MATERIALS AND METHODS}

\section{Animals and Diet}

A Sarda ewe flock, comprising 300 head and located in a lowland area of Livorno province (Tuscany, Italy), 
Table 1. Sampling plan

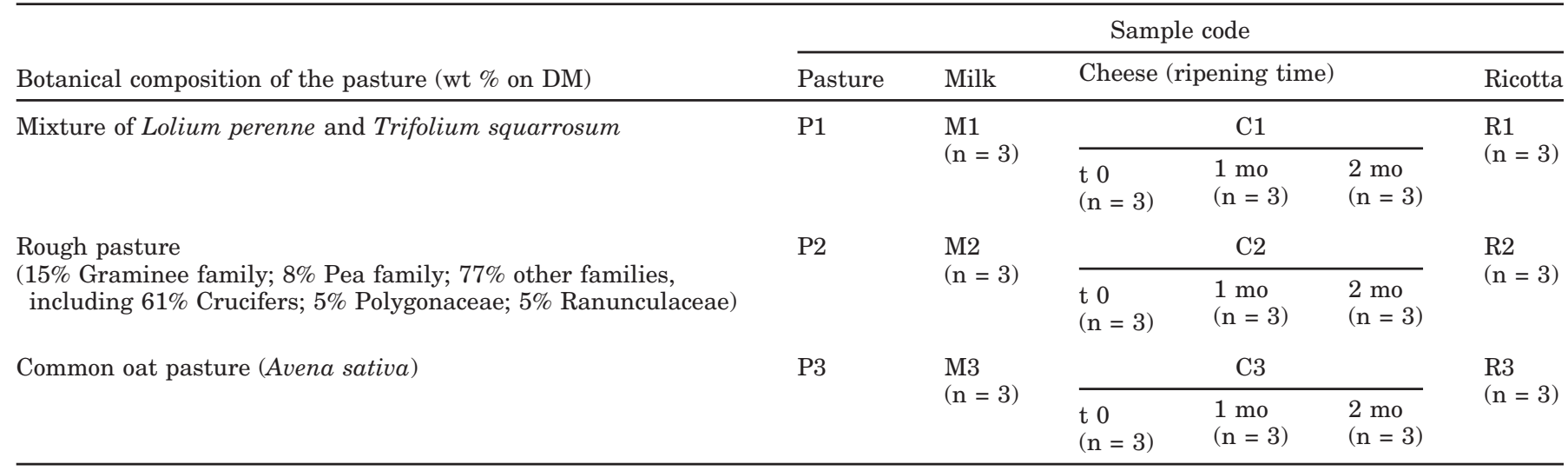

grazed on 3 different types of pasture. Table 1 reports the botanical composition (weight percentage on DM) of the pastures together with the codes adopted for labeling the dairy samples on the basis of the milk origin. Pastures 1 and 3 (P1 and P3) were 2 fields under specific cultivation, whereas pasture 2 (P2) was a rough pasture. For each kind of pasture, grass was cut from $0.5-\mathrm{m}^{2}$ plots in 5 replications. Botanical composition was determined by hand separation. Air-dried herbage samples were divided into the main botanical fractions (grasses, legumes, and herbs) and DM content was determined after drying samples at $105^{\circ} \mathrm{C}$ for $24 \mathrm{~h}$. Each grazing cycle lasted $1 \mathrm{mo}$ : the first $3 \mathrm{wk}$ were the adaptation period and the last week was the experimental period. The overall experimental period lasted $3 \mathrm{mo}$ from April to June.

\section{Cheese Making}

Machine milking was adopted by the farmer. The milk obtained during the experimental periods was used to produce, in a small factory, a 2-mo-old cheese (Caciotta) and whey cheese (ricotta). Technological parameters adopted for the cheese production are described below. Milk was heated at $60^{\circ} \mathrm{C}$ for $15 \mathrm{~min}$, inoculated with a mesophilic starter culture, and coagulated with liquid animal rennet at $35^{\circ} \mathrm{C}$. After $15 \mathrm{~min}$ the curd was cut into small pieces (coffee-bean size), and allowed to stand for $2 \mathrm{~min}$; then it was transferred into the molds, allowing the whey to drain off. The curd was maintained for $2 \mathrm{~h}$ at $25^{\circ} \mathrm{C}$ and during this time, the molds were turned upside down 5 times. A manual dry salting was done by spreading salt evenly over the curd. Cheeses were ripened at the dairy factory for 2 mo at $10^{\circ} \mathrm{C}$ and $85 \%$ relative humidity. Ricotta was produced by using the whey derived from the cheese production: whey was heated at $80^{\circ} \mathrm{C}$ to obtain the rising and coagulation of whey proteins; at the end of this step, proteins were skimmed off manually and transferred into molds, allowing the residual whey to drain off for $2 \mathrm{~d}$ at refrigerating temperature $\left(4^{\circ} \mathrm{C}\right)$.

\section{Milk and Cheese Sampling}

During the last week of each grazing cycle, 3 bulk milk samples (M1, M2, and M3; Table 1) were collected for analysis the day before the cheese making, divided into $50-\mathrm{mL}$ vials, and frozen at $-20^{\circ} \mathrm{C}$. Three Caciotta cheeses $(\mathbf{C 1}, \mathbf{C 2}, \mathbf{C 3})$, from the same batch of production, were collected on the day after cheese making and after 1 and 2 mo of ripening. Three ricotta cheeses $(\mathbf{R 1}$, R2, and R3) were taken immediately after production. Caciotta and ricotta cheeses were divided into portions, vacuum-packed, and stored at $-20^{\circ} \mathrm{C}$ until analysis, which was carried out within 1 mo of storage. Representative samples of the 3 pastures were collected, after having observed the behavior of the sheep flock during grazing, and stored at $-20^{\circ} \mathrm{C}$ until the analysis.

\section{Chemical Composition}

Protein, fat, and ash content were determined on cheese samples according to AOAC (2000) methods.

\section{Volatile Fraction Composition}

A divinylbenzene/carboxen/polydimethylsiloxane, 50/30 $\mu \mathrm{m}, 2$-cm-long fiber was used to collect volatile fractions by SPME. The fiber was conditioned at $270^{\circ} \mathrm{C}$ for $30 \mathrm{~min}$ in a GC split/splitless injector before analysis. Fifteen grams of milk, $6 \mathrm{~g}$ of grated cheese, $10 \mathrm{~g}$ of ricotta, or $5 \mathrm{~g}$ of pasture, roughly cut into small pieces shortly before the analysis, was weighed in a $20-\mathrm{mL}$ crimp-top vial, and sealed with an aluminum cap provided with a pierceable septum $(23 \times 75 \mathrm{~mm}$, Varian, Palo Alto, CA). Milk, cheese, and ricotta samples were 
Table 2. Volatile compounds extracted from pasture

\begin{tabular}{|c|c|c|c|c|c|}
\hline \multirow[b]{2}{*}{ Compound $^{1}$} & \multicolumn{3}{|c|}{ Pasture } & \multirow{2}{*}{$\begin{array}{l}\text { Retention } \\
\text { index }\end{array}$} & \multirow{2}{*}{$\begin{array}{l}\text { Identification } \\
\text { method }^{2}\end{array}$} \\
\hline & $\mathrm{P} 1$ & $\mathrm{P} 2$ & P3 & & \\
\hline Dimethyl sulfide & $t^{3}$ & + & $-^{4}$ & 751 & PI \\
\hline Acetone & - & - & + & 812 & PI \\
\hline 2-Butanone & - & - & + & 893 & PI \\
\hline 2-Methyl butanal & + & + & - & 917 & PI \\
\hline 3-Methyl butanal & ++ & + & - & 922 & MS/PI \\
\hline Ethanol & ++ & ++ & + & 938 & MS/PI \\
\hline 2,2,4,6,6-Pentamethyl eptane & ++ & ++ & ++ & 943 & \\
\hline 2-Pentanone & - & - & ++ & 981 & MS/PI \\
\hline$\alpha$-Pinene & - & ++ & - & 1,027 & MS/PI \\
\hline$\alpha$-Thujene & - & ++ & - & 1,033 & PI \\
\hline Toluene & - & - & ++ & 1,051 & MS/PI \\
\hline Hexanal & ++ & ++ & + & 1,090 & MS/PI \\
\hline$\beta$-Pinene & - & ++ & - & 1,105 & MS/PI \\
\hline Sabinene & - & + & - & 1,124 & PI \\
\hline$\Delta 3$-Carene & - & + & - & 1,154 & PI \\
\hline 1-Penten-3-ol & - & - & ++ & 1,166 & PI \\
\hline$\alpha$-Phellandrene & - & + & - & 1,170 & PI \\
\hline Myrcene & - & + & - & 1,172 & PI \\
\hline Limonene & - & ++ & - & 1,200 & MS/PI \\
\hline 3-Methyl-1-butanol & - & ++ & - & 1,212 & MS/PI \\
\hline t-2-Hexenal & ++++ & ++ & + & 1,226 & PI \\
\hline$\beta$-Ocimene & - & + & - & 1,246 & PI \\
\hline$\gamma$-Terpinene & - & + & - & 1,253 & PI \\
\hline 1-Pentanol & - & - & + & 1,256 & PI \\
\hline 3-Octanone & ++ & + & - & 1,262 & PI \\
\hline 1-Octen-3-one & + & - & - & 1,309 & PI \\
\hline Cis-2-pentenol & + & + & + & 1,325 & \\
\hline 1-Hexanol & ++ & ++ & + & 1,357 & PI \\
\hline c-3-Hexen-1-ol & ++ & +++ & ++ & 1,387 & PI \\
\hline t-2-Hexen-1-ol & ++ & ++ & + & 1,410 & PI \\
\hline t,t-2,4-Hexadienal & ++ & + & - & 1,411 & \\
\hline 1-Octen-3-ol & ++ & ++ & + & 1,454 & PI \\
\hline$\alpha$-Cubebene & - & ++ & - & 1,466 & PI \\
\hline$\alpha$-Copaene & - & + & - & 1,502 & PI \\
\hline Benzaldehyde & - & + & - & 1,537 & PI \\
\hline$\beta$-Cubebene & - & + & - & 1,548 & PI \\
\hline t2,c6-Nonadienal & + & - & - & 1,596 & PI \\
\hline$\beta$-Caryophyllene & - & ++ & - & 1,607 & PI \\
\hline $\mathrm{t}$ - $\beta$-Farnesene & - & + & - & 1,669 & PI \\
\hline$\alpha$-Humulene & - & + & - & 1,684 & PI \\
\hline Germacrene D & - & + & - & 1,722 & PI \\
\hline$\Delta$-Cadinene & - & ++ & - & 1,765 & PI \\
\hline$\gamma$-Cadinene & - & + & - & 1,769 & PI \\
\hline Methyl salicylate & - & - & + & 1,787 & PI \\
\hline Naphtalene & - & + & - & 1,789 & \\
\hline Benzyl alcohol & - & + & - & 1,879 & PI \\
\hline$\alpha$-Bisabolol & - & + & - & 2,222 & PI \\
\hline
\end{tabular}

\footnotetext{
${ }^{1}$ Identification by comparison with mass spectra of Wiley library (McLafferty and Stauffer, 1988).

${ }^{2}$ Identification methods: PI = retention indexes published (Jennings and Shibamoto, 1980; Acree and Arn, 2004); MS = mass spectra of authentic compounds.

${ }^{3}$ Range of area unit/100,000: $+=0$ to $50 ;++=50$ to $500 ;+++=500$ to 1,$000 ;++++=$ more than 1,000 .

${ }^{4}$ Not detected in pasture sample.
}

allowed to equilibrate to $45^{\circ} \mathrm{C}$ in a thermostatic bath for $5 \mathrm{~min}$ and the fiber was exposed to the headspace for $30 \mathrm{~min}$. During the extraction, milk samples were kept under agitation by a microstir bar placed into the vial. The extraction of volatile compounds from pasture was performed in duplicate, maintaining the sample at room temperature, and exposing the fiber to the headspace for $15 \mathrm{~min}$.
The gas chromatographic analysis of volatile compounds adsorbed on the SPME fiber was carried out with a CP-WAX 52CB capillary column (Varian; $60 \mathrm{~m}$ long, $0.32 \mathrm{~mm}$ i.d., $0.5 \mu \mathrm{m}$ film thickness). A Hewlett Packard (Palo Alto, CA) 5890 series II gas chromatograph coupled with a Hewlett Packard 5989A mass spectrometer was used. To achieve sharper peaks, the split/splitless injector was provided with a $0.75 \mathrm{~mm}$ i.d. 

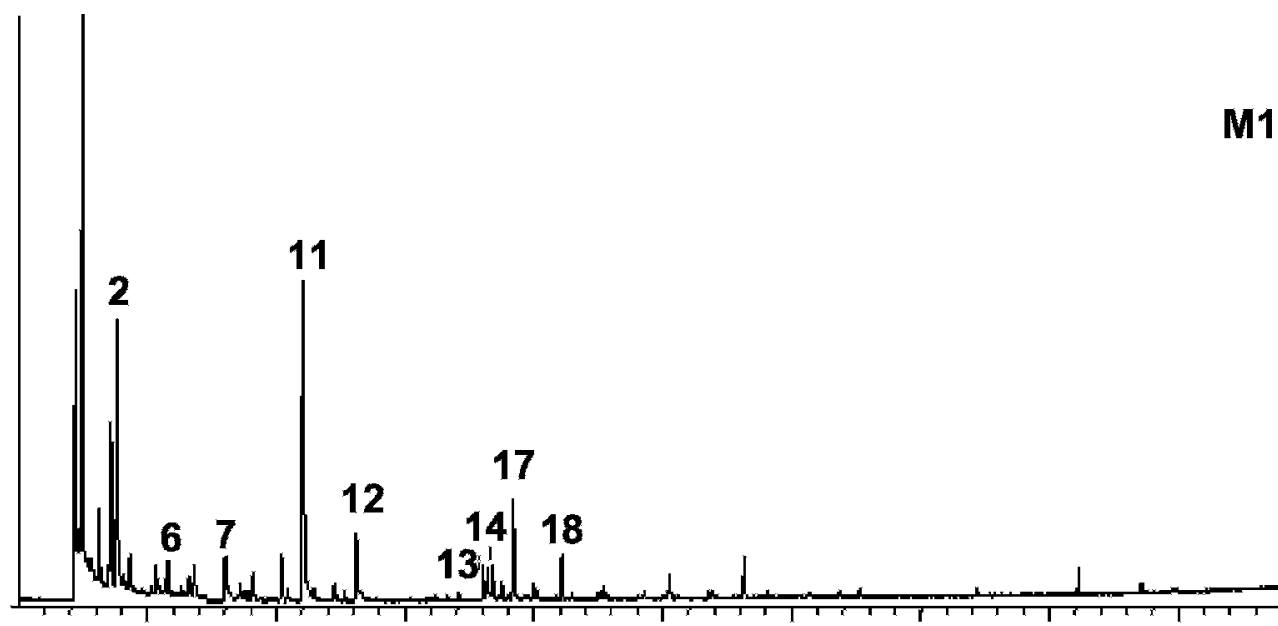

M1

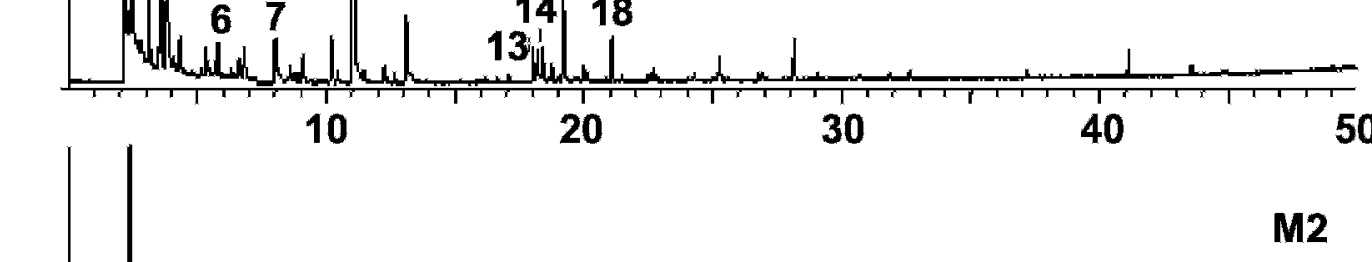

11

$12 \quad 17$

\begin{tabular}{r|r}
14 & 18
\end{tabular}

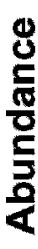

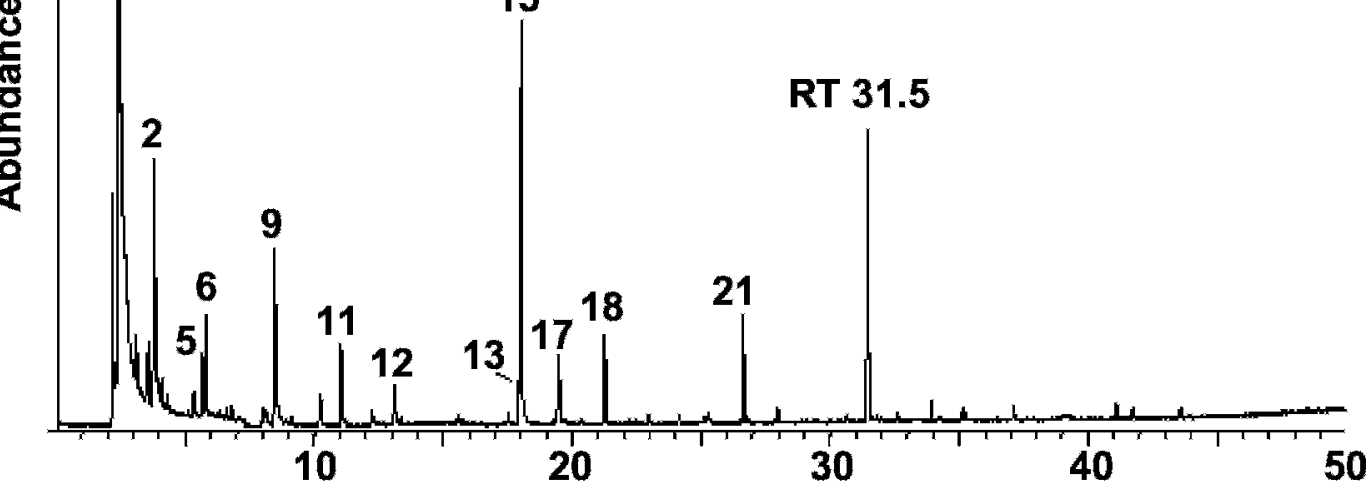

19

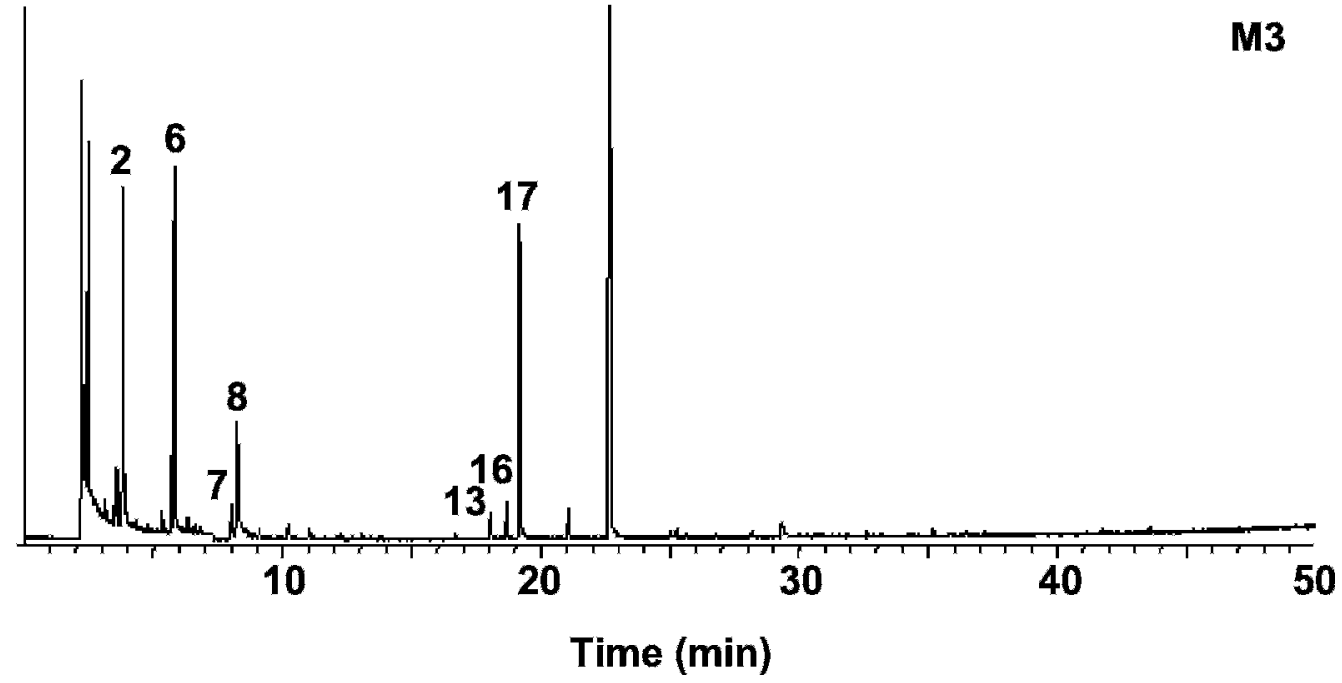

Figure 1. Solid-phase microextraction/GC-MS profiles of milk samples M1, M2, and M3 (peaks are numbered as in Table 3). 
Table 3. Volatile compounds of milk and ricotta cheese (retention indexes and means of the area values/ 100,000 of the 3 replicates)

\begin{tabular}{|c|c|c|c|c|c|c|c|c|c|c|}
\hline \multirow[b]{2}{*}{ Peak } & \multirow[b]{2}{*}{ Compound $^{1}$} & \multicolumn{2}{|c|}{$\begin{array}{l}\text { Retention } \\
\text { indices }^{2}\end{array}$} & \multirow{2}{*}{$\begin{array}{l}\text { Identification } \\
\text { method }^{3}\end{array}$} & \multicolumn{3}{|c|}{ Milk } & \multicolumn{3}{|c|}{ Ricotta } \\
\hline & & Milk & Ricotta & & M1 & M2 & M3 & $\mathrm{R} 1$ & $\mathrm{R} 2$ & R3 \\
\hline 1 & Dimethyl sulfide & & 753 & PI & $-^{4}$ & - & - & 0.7 & 1.6 & 2.7 \\
\hline 2 & Acetone & 811 & 823 & MS/PI & 19.6 & 20.6 & 23.5 & 12.1 & 36.1 & 25.2 \\
\hline 3 & 3-Octene & 840 & 841 & & - & - & - & 3.2 & 9.7 & - \\
\hline 4 & 2-Butanone & 906 & 906 & MS/PI & - & - & - & 1.4 & 4.9 & 3.5 \\
\hline 5 & 2-Methyl butanal & 905 & & MS/PI & - & 4.5 & - & - & - & - \\
\hline 6 & 3-Methyl butanal & 910 & & MS/PI & 2.4 & 7.7 & 27.9 & - & - & - \\
\hline 7 & 2-Pentanone & 971 & 984 & MS/PI & 2.8 & - & 3.0 & 3.0 & 11.9 & 6.0 \\
\hline 8 & Diacetyl & 976 & & MS/PI & - & - & 12.8 & - & - & - \\
\hline 9 & Methyl butyrate & 982 & & MS/PI & - & 17.9 & - & - & - & - \\
\hline 10 & Pentanal & & 986 & MS/PI & - & - & - & 3.9 & 16.2 & 6.0 \\
\hline 11 & Toluene & 1,043 & 1,051 & MS/PI & 29.8 & 8.5 & - & 0.8 & 15.6 & - \\
\hline 12 & Hexanal & 1,087 & 1,089 & MS/PI & 4.9 & 3.4 & - & 1.2 & 3.8 & 1.6 \\
\hline 13 & 2-Heptanone & 1,182 & 1,189 & $\mathrm{MS} / \mathrm{PI}$ & 2.6 & 3.5 & 1.8 & 4.5 & 18.4 & 7.3 \\
\hline 14 & Heptanal & 1,186 & 1,192 & PI & 2.2 & - & - & 1.6 & 3.9 & 0.8 \\
\hline 15 & Methyl hexanoate & 1,184 & 1,191 & MS/PI & - & 32.3 & - & - & 1.5 & - \\
\hline 16 & Limonene & 1,195 & & MS/PI & - & - & 2.6 & - & - & - \\
\hline 17 & 3-Methyl-1-butanol & 1,208 & 1,215 & MS/PI & 7.9 & 5.9 & 25.1 & - & 4.2 & 0.8 \\
\hline 18 & 1-Pentanol & 1,257 & 1,259 & PI & 3.6 & 6.4 & - & 1.1 & 5.5 & 1.8 \\
\hline 19 & Acetoin & 1,292 & 1,295 & PI & - & - & 82.7 & - & 2.8 & - \\
\hline 20 & 2-Nonanone & & 1,392 & MS/PI & - & - & - & 1.0 & 2.8 & 0.8 \\
\hline 21 & Methyl octanoate & 1,390 & & MS/PI & - & 7.0 & - & - & - & - \\
\hline \multirow[t]{2}{*}{22} & Nonanal & & 1,396 & PI & - & - & - & 1.0 & 1.3 & 0.7 \\
\hline & RT 31.5 & 1,529 & 1,529 & & - & 21.5 & - & - & 36.6 & - \\
\hline 23 & Butyric acid & & 1,636 & MS/PI & - & - & - & - & 2.2 & 2.5 \\
\hline 24 & Hexanoic acid & & 1,845 & $\mathrm{MS} / \mathrm{PI}$ & - & - & - & - & 1.4 & 3.0 \\
\hline 25 & Dimethylsulphone & & 1,914 & & - & - & - & 1.5 & 1.8 & 0.4 \\
\hline 26 & Octanoic acid & & 2,069 & MS/PI & - & - & - & 1.6 & - & 2.2 \\
\hline 27 & Decanoic acid & & 2,276 & MS/PI & - & - & - & 1.8 & - & - \\
\hline
\end{tabular}

${ }^{1}$ Identification by comparison with mass spectra of Wiley library (McLafferty and Stauffer, 1988).

${ }^{2} \mathrm{RI}=$ Retention index measured in milk and ricotta cheese samples.

${ }^{3} \mathrm{PI}=$ Retention indexes published (Jennings and Shibamoto, 1980; Acree and Arn, 2004); MS = mass spectra of authentic compounds.

${ }^{4}$ Not detected in any of the 3 milk or ricotta cheese samples.

inlet liner (Supelco, Bellefonte, PA). During the injection phase, a 3-min splitless mode was applied and the injector temperature was held at $250^{\circ} \mathrm{C}$. Oven temperature was held at $40^{\circ} \mathrm{C}$ for $8 \mathrm{~min}$, programmed to $220^{\circ} \mathrm{C}$ at a rate of $4^{\circ} \mathrm{C} / \mathrm{min}$, and held at $220^{\circ} \mathrm{C}$ for $20 \mathrm{~min}$. Helium was used as a carrier gas at a flow rate of 1.0 $\mathrm{mL} / \mathrm{min}$. The MS temperatures adopted were as follows: interface $220^{\circ} \mathrm{C}$, source $200^{\circ} \mathrm{C}$, quadrupole $100^{\circ} \mathrm{C}$; acquisition was performed in electron impact (EI) mode (70 eV) by 1.6 scans per second and the mass range used was $\mathrm{m} / \mathrm{z} 35$ to 270 .

The identification of volatile compounds was performed with the following criteria: comparison with the mass spectra of the Wiley library (McLafferty and Stauffer, 1988), injection of authentic standards analyzed under the same GC-MS conditions, calculation of retention indices (RI) followed by comparison with those obtained from both authentic standards and literature (Jennings and Shibamoto, 1980; Acree and Arn, 2004).
The identification of the compound at RI 1,529 was performed by applying positive and negative chemical ionization. A Finnigan PolarisQ mass spectrometer (Thermo Electron, Milan, Italy) was used with the same GC column adopted in the EI analysis: the source temperature was at $150^{\circ} \mathrm{C}$ and reagent gases ammonia (1.5 $\mathrm{mL} / \mathrm{min})$, isobutane $(1 \mathrm{~mL} / \mathrm{min})$, methane $(1.5 \mathrm{~mL} / \mathrm{min})$ were tested.

\section{Statistical Analysis}

Data for cheese volatile compounds were subjected to principal components analysis (PCA) using the PARVUS package (Forina et al., 1988). Statistical evaluation was performed on the data obtained from SPME analysis. The data set consisted of the 27 samples (objects), reported in Table 1 , and 15 volatile compounds (variables), with the following changes: area values of carboxylic acids (acetic, butyric, isobutyric, isopentanoic, hexanoic, octanoic, and decanoic acids) were 


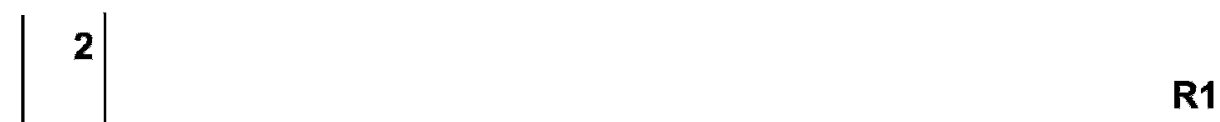

R1

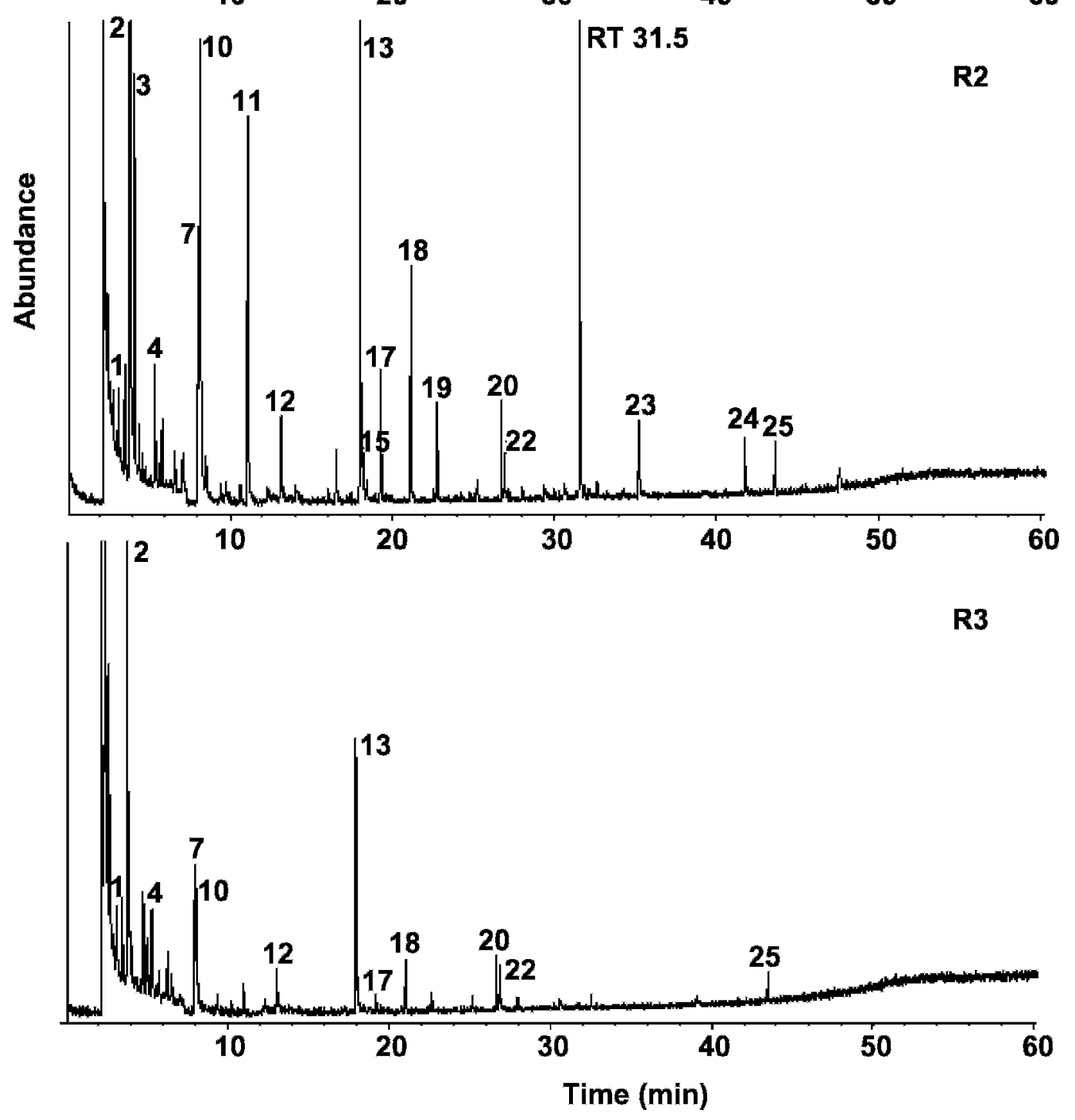

Figure 2. Solid-phase microextraction/GC-MS profiles of ricotta cheese samples R1, R2, and R3 (peaks are numbered as in Table 3). 
Table 4. Caciotta cheese volatile compounds: mean values (area unit/100,000) of the 3 replicates of the samples collected at each ripening time

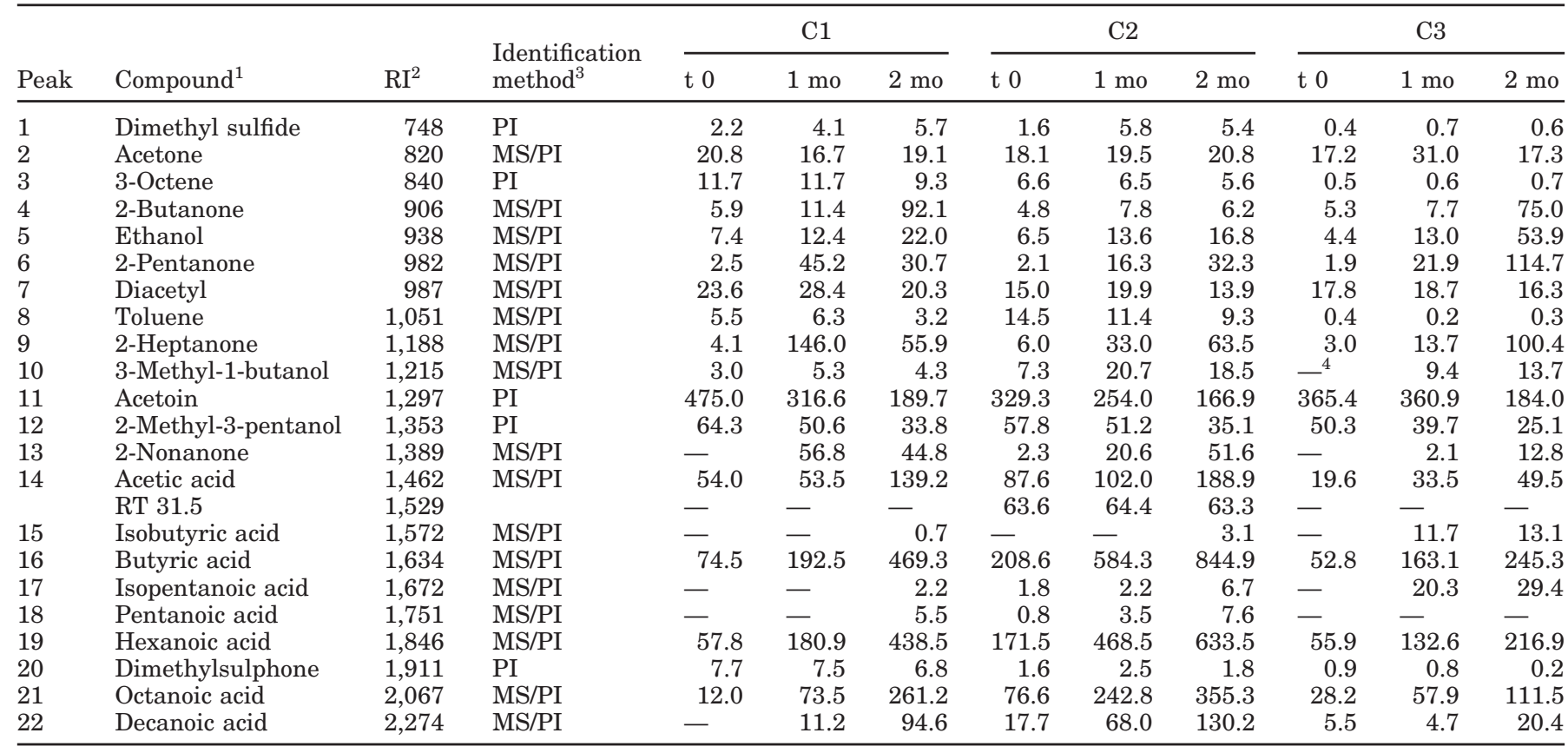

${ }^{1}$ Identification by comparison with mass spectra of Wiley library (McLafferty and Stauffer, 1988).

${ }^{2} \mathrm{RI}=$ Retention index measured in cheese samples.

${ }^{3} \mathrm{PI}=$ Retention indexes published (Jennings and Shibamoto, 1980; Acree and Arn, 2004); MS = mass authentic compounds

${ }^{4}$ Not detected in any of the 3 samples.

summed and treated as unique variables, labeled as "acids"; the compound having RI 1,529 was excluded from the data set. The PCA was applied using the correlation matrix (Pearson).

\section{RESULTS AND DISCUSSION}

\section{Volatile Fraction of Pastures}

The analysis of the volatile fraction of the 3 pastures by SPME/GC-MS analysis showed important differences among the samples (Table 2). Due to the variety of its botanical composition, the rough pasture (P2) was characterized by a very rich profile, especially when compared with $\mathrm{P} 1$. In the volatile fraction of $\mathrm{P} 2$, the most abundant compounds were alcohols and terpenes, the latter class being absent in the profiles of the other 2 pastures. Oat pasture (P3) had a volatile composition rich in alcohols, both saturated and unsaturated, and it was characterized by the presence of methyl salicylate.

\section{Volatile Fraction of Milk}

Differences in the volatile composition of milk samples were observed. Milk M2 provided the richest profile with respect to the milk samples deriving from the other
2 pastures (Figure 1). The presence of methyl esters (peaks 9,15 , and 21) and, in particular, of a compound at retention time 31.5 , having $\mathrm{RI} 1,529$, seemed to be characteristic of this milk. The peak at RI 1,529 was detected in all $3 \mathrm{M} 2$ samples collected. On the other hand, M3 was characterized by the presence of diacetyl (peak 8) and acetoin (peak 19), substances deriving from the microbial metabolism of citrate. Moreover, toluene (peak 11) was detected only in milks M1 and M2 (Table 3). The presence of esters, aldehydes, ketones, alcohols, and toluene in ovine milk was previously detected by Moio et al. (1993a).

\section{Volatile Fraction of Ricotta and Caciotta Cheeses}

To characterize the cheeses produced with regard to their chemical composition, analyses of protein, fat, and ash content were performed. The mean values obtained for protein, fat, and ash content were 9.3, 8.8, and $1 \%$ for ricotta samples and 27.2, 28.5, and $1.9 \%$ for the 2mo-old Caciotta cheese samples. The data obtained were in accordance with those reported for these types of products.

Volatile fractions of ricotta cheese varied for all 3 types of pastures. Figure 2 shows the GC-MS profiles 


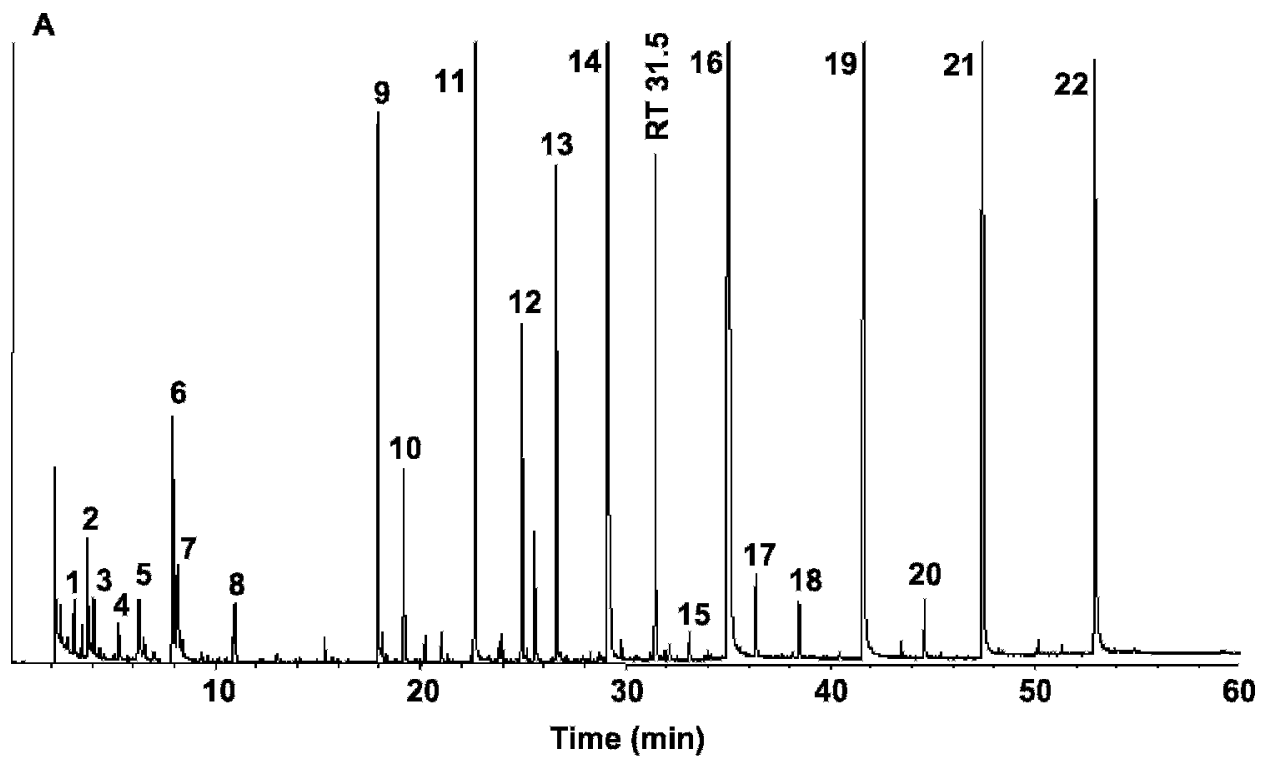

B
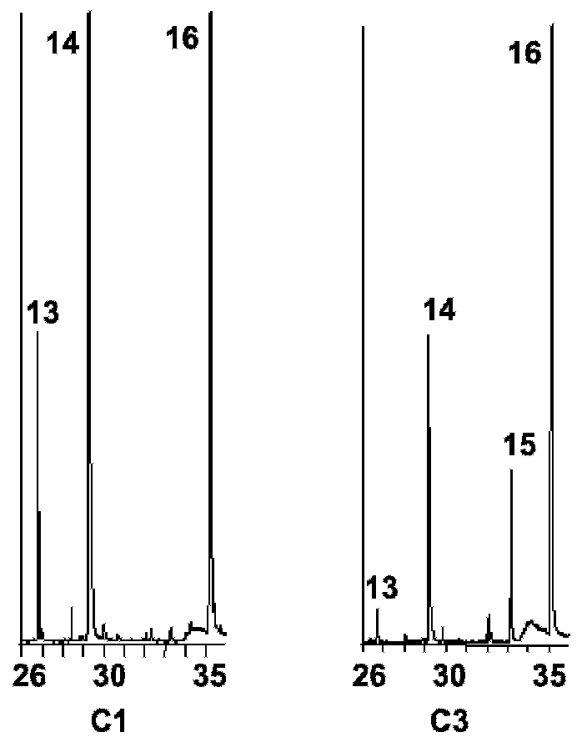

Figure 3. Solid-phase microextraction/GC-MS profiles of Caciotta cheese samples at 2 mo of ripening: A) total chromatogram of C2 sample; B) enlarged view of chromatograms of C1 and C3 samples. Peaks are numbered as in Table 4; C1, C2, and C3 represent cheeses made from milk from ewes pastured on each of 3 pastures.

of the 3 samples, and Table 3 reports the area values of the volatile compounds. The R2 sample showed the richest SPME/GC-MS profile under both a qualitative and quantitative point of view. Some correspondences with milk samples can be observed: particularly, toluenes were detected only in R1 and R2 (as was the case in M1 and M2). Moreover, 3-octene was detected only in R1 and R2 samples. The more interesting aspect was the presence of the compound at RI 1,529 in the GCMS profile of R2.
The volatile fraction of the Caciotta cheese was analyzed at different ripening periods. Table 4 reports the data of area values obtained at the different ripening steps for each cheese production: mean values were calculated from the analyses performed on the 3 cheese samples produced on the same day from the same milk. Two sulfur compounds were detected: dimethyl sulfide, which is derived both from feed (Reddy et al., 1967) and by catabolism of sulfur amino acids, particularly methionine (McSweeney and Sousa, 2000), and dimeth- 

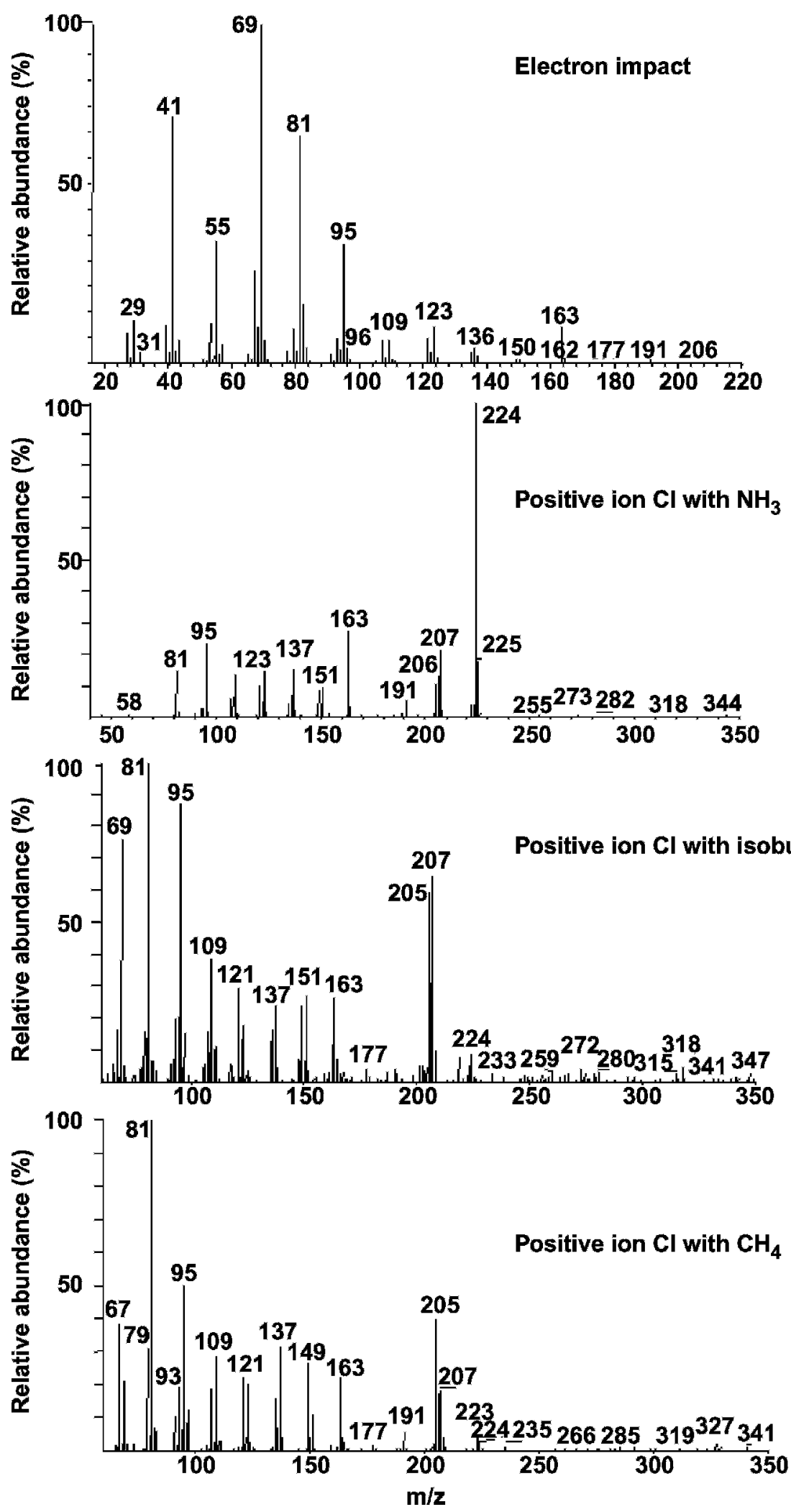

Figure 4. Electron impact and chemical ionization (CI) spectra of the unknown compound eluting at 31.5 min. 
Table 5. Loading (\%) for volatile compounds on the first 3 eigenvectors $^{1}$

\begin{tabular}{lrrr}
\hline Compound & PC1 & PC2 & PC3 \\
\hline Dimethyl sulfide & 3.45 & 14.97 & 4.98 \\
Acetone & 0.75 & 1.91 & 1.30 \\
3-Octene & 0.03 & 22.08 & 0.98 \\
2-Butanone & 9.97 & 0.58 & 5.17 \\
Ethanol & 13.37 & 4.47 & 1.94 \\
2-Pentanone & 12.70 & 2.15 & 5.21 \\
Toluene & 0.34 & 9.54 & 12.21 \\
Diacetyl & 0.09 & 7.03 & 14.95 \\
2-Heptanone & 9.38 & 2.75 & 7.52 \\
3-Methyl-1-butanol & 4.39 & 0.00 & 17.80 \\
Acetoin & 17.17 & 0.08 & 3.48 \\
2-Methyl-3-pentanol & 13.45 & 4.76 & 0.00 \\
2-Nonanone & 7.23 & 10.07 & 0.21 \\
Dimethylsulfone & 0.01 & 16.49 & 9.08 \\
Acids & 7.68 & 3.19 & 15.17 \\
\% of variance explained & 32.17 & 25.42 & 17.55 \\
\% of total variance & 32.17 & 57.59 & 75.14 \\
\hline
\end{tabular}

${ }^{1} \mathrm{PC}=$ principal component

ylsulfone, whose presence in milk has been related to animal metabolism (Williams et al., 1966). Dimethyl sulfide was higher in $\mathrm{C} 2$ cheese and it increased during the first month, whereas dimethylsulfone was more abundant in cheese $\mathrm{C} 1$ and did not change during ripening. Acetone was present in similar amounts in the 3 cheese categories and did not show changes during ripening; its presence in cows' milk was related to feeding (Gordon and Morgan, 1972). Diacetyl, acetoin, and 2-butanone are produced by the metabolic pathways of citrate (McSweeney and Sousa, 2000; Marilley and Casey, 2004). Acetoin was the most abundant volatile compound detected immediately after production in all cheese samples and it decreased during ripening. Diacetyl was higher in cheese C1 than in C2 and C3 and it showed the same behavior for the 3 pastures during ripening, having a slight increase at $1 \mathrm{mo}$ and a decrease at 2 mo. 2-Butanone had the same area values for C1, C2, and C3 immediately after production, but showed a strong increase at $2 \mathrm{mo}$ of ripening in samples $\mathrm{C} 1$ and C3. For alcohols, ethanol, 3-methyl-1-butanol, and 2-methyl-3-pentanol were detected. Ethanol, deriving from lactose microbial fermentation (Marilley and Casey, 2004), was found at the same level in all samples collected immediately after production and its increase during ripening showed the same rate in samples $\mathrm{C} 1$ and $\mathrm{C} 2$, whereas it was more intense in sample C3. 3Methyl-1-butanol, which derives from the metabolism of leucine (Yvon and Rijnen, 2001), showed an increase only in samples C2 and C3. 2-Methyl-3-pentanol was found in the same amount in the 3 types of cheese and decreased during ripening. The amount of 2-pentanone, 2-heptanone, and 2-nonanone, which are produced from $\beta$-oxidation and decarboxylation of free fatty acids $\beta$-farnesene

(E)-7,11-dimethyl-3-methylene-1,6,10-dodecatriene

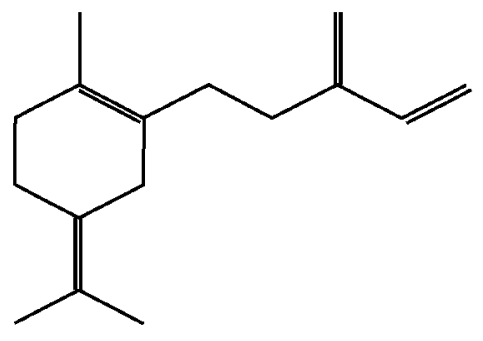

(E,E)-3,7,11-trimethyl-2,4,10-dodecatriene

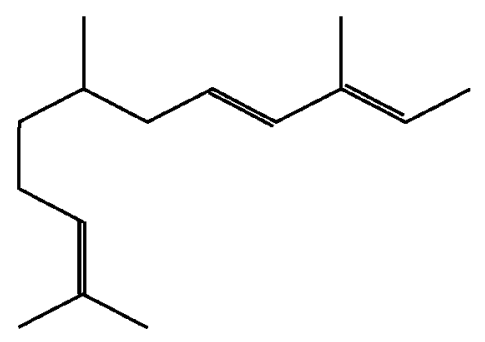

Figure 5. Molecular structures of $\beta$-farnesene and (E,E)-3,7,11trimethyl-2,4,10-dodecatriene.

(Marilley and Casey, 2004), was comparable in all the samples analyzed immediately after production. During ripening, these compounds showed a progressive increase in samples $\mathrm{C} 2$ and $\mathrm{C} 3$, whereas in $\mathrm{C} 1$ they reached the highest value after $1 \mathrm{mo}$ and then decreased or remained constant. Straight and branched-chain VFA, ranging from 2 to 10 carbon atoms, were detected. Low molecular weight fatty acids (C2 to C10) can be formed by both fat lipolysis and microbial metabolism (Yvon and Rijnen, 2001), whereas isobutyric and isopentanoic acids derive from the microbial catabolism of valine and leucine, respectively (Yvon and Rijnen, 2001). The $\mathrm{C} 2$ cheese samples showed (at first sampling and during ripening) the highest amount of straightchain fatty acids. On the other hand, C3 samples were characterized by a higher amount of isobutyric and isopentanoic acids than $\mathrm{C} 1$ and $\mathrm{C} 2$. As regards hydrocarbons, 2 compounds were found: the monounsaturated 3 -octene and the aromatic toluene. 3-Octene, which probably derived from oxidation of unsaturated fatty acids (Frankel, 1980), has previously been found in the volatile fraction of other cheeses, such as Roncal and Pecorino Sardo (Larráyoz et al., 2001). This compound, whose presence in our samples was not affected by the ripening period, was detected in $\mathrm{C} 1$ cheeses at a level twice that in $\mathrm{C} 2$, whereas in C3 it was very low. It is worth noting that, with regard to ricotta cheese, 3-oc- 


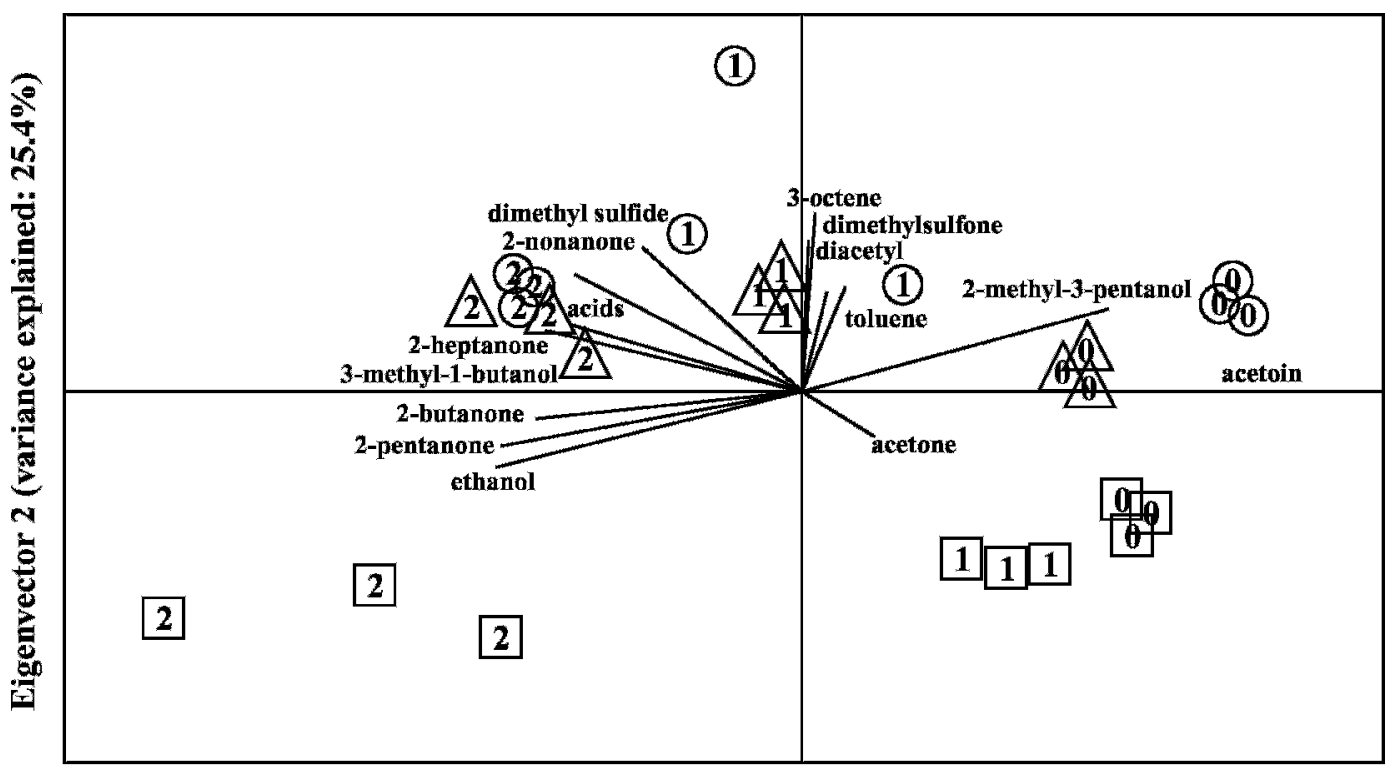

Eigenvector 1 (variance explained: 32.2\%)

Figure 6. Principal components analysis biplot on the first and second eigenvector (57.6\% of the total variance explained) of 27 samples (objects) and 15 volatile compounds (variables) in $\mathrm{C} 1(\bigcirc)$; $\mathrm{C} 2(\triangle), \mathrm{C} 3(\square)$; C1, C2, and C3 represent cheeses made from milk from ewes pastured on each of 3 pastures. Numbers inside the symbols indicate the ripening time: immediately after production (0), 1 mo (1), and 2 mo (2).

tene was detected only in R1 and R2 samples. Toluene, which was detected in M1 and M2 milks, was found only in $\mathrm{C} 1$ and $\mathrm{C} 2$ cheeses. The reason of the presence of toluene in milk and cheese remains unclear. Moio et al. (1993b), referring to the research of Drawert et al. (1981), who described a natural origin of this compound as a degradation product of $\beta$-carotene, hypothesized a direct transfer from forage into milk. The recent researches of Spinhirne et al. (2003, 2004), who found toluene in the volatile profile of ruminal cultures (2003) and bovine breath (2004), seemed to support this assumption. On the other hand, regarding cheese, Bosset et al. (2000) observed that the freeze storage and packaging materials might be the origin of some benzene derivatives, including toluene; however, these researchers also put forward the hypothesis that these compounds could also have a microbial origin.

The most interesting difference among the cheeses was the presence of the same volatile substance appearing in M2 and R2 samples at RI 1,529 and detected (in all 3 sampling periods) in the GC-MS profile of cheese C2. Figure 3 reports the total SPME/GC-MS profile of the volatile fraction obtained from sample $\mathrm{C} 2$ at 2 mo of ripening together with the enlarged views of the time range 26 to $35 \mathrm{~min}$ of $\mathrm{C} 1$ and $\mathrm{C} 3$ at the same ripening time.

The EI spectrum of the compound at RI 1,529 (Figure 4) was compared with those of both Wiley library and authentic standards of the most common volatiles but it did not match any compound satisfactorily. The type of fragmentation deriving from EI mode allowed some inferences about its structure to be made. This compound could have a molecular weight of 206 , and the presence of fragments with sequential addition of methylene units (14 amu), together with the intensity of the ions $\mathrm{C}_{\mathrm{n}} \mathrm{H}_{2 \mathrm{n}-1}$, lead to the hypothesis that this molecule could be an unsaturated hydrocarbon. Moreover, fragment ions with $\mathrm{m} / z 123$ and 136, even though not particularly intense, suggested the presence of a terpenic structure. To obtain more information, chemical ionization (CI) with methane, isobutane, and ammonia was performed, in both positive- and negative-ion mode. The substance provided, in CI positive-ion mode, a very fragmented spectrum, as expected by an unsaturated hydrocarbon. By operating with $\mathrm{CH}_{4}$, the presence of ions $m / z 205\left(\mathrm{M}-\mathrm{H}^{+}\right)$and $207\left(\mathrm{M}+\mathrm{H}^{+}\right)$confirmed the molecular weight of 206. This result was also demonstrated by the ions $m / z 207\left(\mathrm{M}+\mathrm{H}^{+}\right)$and $224\left(\mathrm{M}+\mathrm{NH}_{4}{ }^{+}\right)$, obtained with $\mathrm{NH}_{3}$ and isobutane. The negative chemical ionization using the 3 reagent gases did not produce other useful information. From the evaluation of these results, no complete identification of the compound at RI 1,529 was achieved, but it can be reasonably concluded that it was an unsaturated hydrocarbon (molecular weight of 206) with a terpenic structure. Moreover, a high degree of similarity was found between its EI 


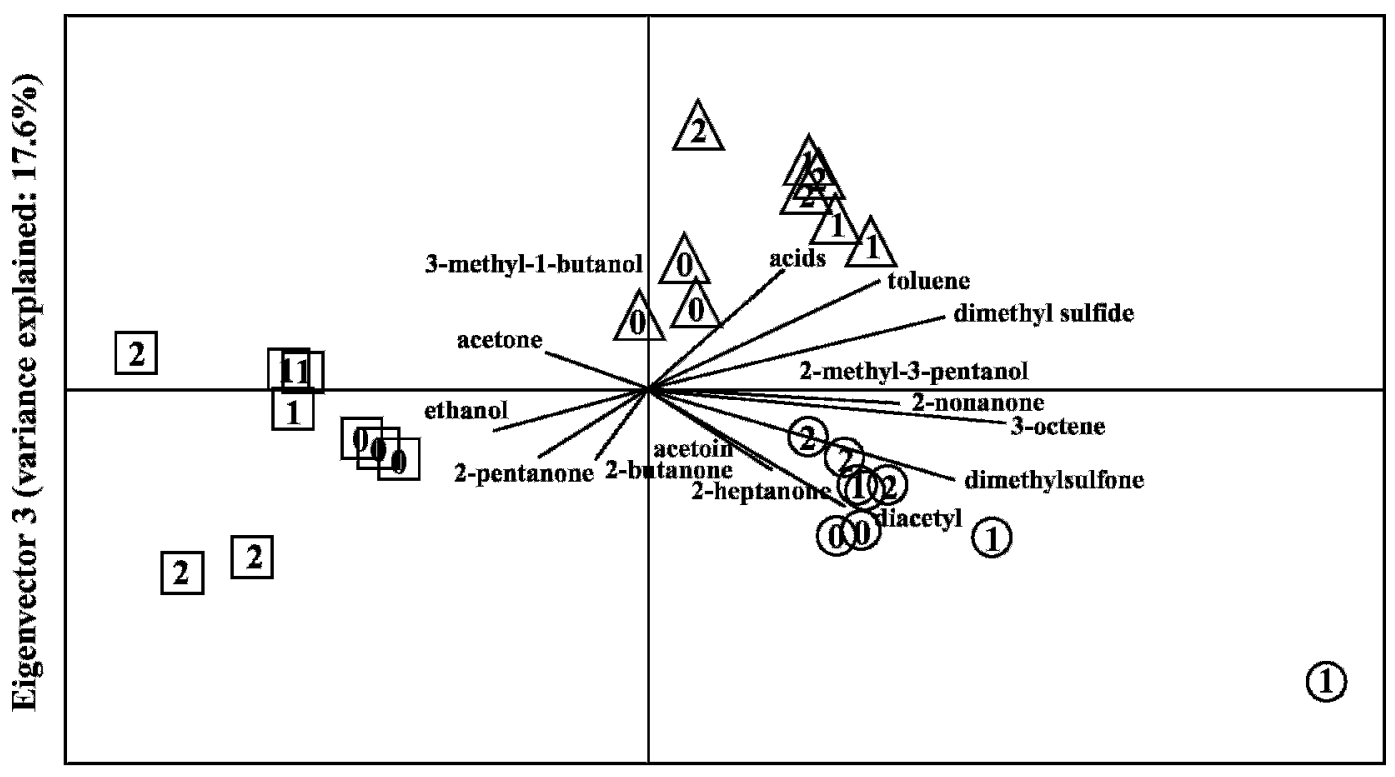

Eigenvector 2 (variance explained: $\mathbf{2 5 . 4 \%}$ )

Figure 7. Principal components analysis biplot on the second and third eigenvector ( $43 \%$ of the total variance explained) of 27 samples (objects) and 15 volatile compounds (variables) in C1 (O); C2 $\triangle$ ); C3 ( $\square$ ); C1, C2, and C3 represent cheeses made from milk from ewes pastured on each of 3 pastures. Numbers inside the symbols indicate the ripening time: immediately after production (0), 1 mo (1), and 2 mo (2).

mass spectrum and that of some compounds reported in literature. Moio et al. (1996) found 2 compounds identified as sesquiterpenes and having a molecular weight of 206; the mass spectrum of one of them (peak 74) had strong similarity to that of our unknown molecule at RI 1,529. In addition, another affinity was observed with (E,E)-3,7,11-trimethyl-2,4,10-dodecatriene $\left(\mathrm{C}_{15} \mathrm{H}_{26}\right)$, identified by Palomino et al. (1996), who reported for this compound the following EI fragmentation $\mathrm{m} / z$ (relative abundance): 206(10), 191(9), 177(5), $163(20), 149(8), 136(22), 121(43), 109(58), 95(75)$, $81(42), 69(100), 55(58)$. The compound at RI 1,529 could be an isomer of (E,E)-3,7,11-trimethyl-2,4,10-dodecatriene. By looking at the molecular structure of this substance and at the volatile compounds present in $\mathrm{P} 2$, a possible origin from $\beta$-farnesene can be assumed (Figure 5), according to the results showed by Schlichtherle-Cerny et al. (2004). Some unsaturated hydrocarbons, tentatively identified as 3,7-dimethyl-1,6-octadiene, 2,6-dimethyl-2,6-octadiene, and 3,7-dimethyl-2octene, were found by these researchers in milk but not in grass. After studying the rumen reactions occurring on some components of the pastures, the authors observed a correlation between the formation of these compounds and the degradation of $\beta$-myrcene and (E)$\beta$-ocimene. The same mechanism of reaction can explain the formation of (E,E)-3,7,11-trimethyl-2,4,10-dodecatriene from $\beta$-farnesene.
To get an overall evaluation of the influence of pasture on the evolution of volatile compounds during the ripening period, PCA was applied to the results obtained from the cheese samples (Figure 6). The compound having RI 1,529 was not included in the data set due to its obvious discriminating ability. The 3 ripening periods (labeled as 0,1, and 2) are distinguished along the axis of the first eigenvector, where ketones and 2methyl-3-pentanol had the highest loading (Table 5). The separation according to the type of pasture is really obtained only for C3 (in squares), along the axis of the second eigenvector. Good discrimination among the 3 types of pasture is obtained by taking into account the information contained in components 2 and 3 (Figure 7 ), explaining the $43 \%$ of the total variance. It is worth noting that the separation among the 3 pastures occurs along the axes of both components. The variables contributing more to the second eigenvector (3-octene, dimethylsulfone, and dimethyl sulfide) seemed to be able to distinguish P3 from the other 2 pastures, whereas those contributing more to the third eigenvector (toluene, diacetyl, 3-methyl-1-butanol, and acids) were able to distinguish pasture 1 from pasture 2 .

The different composition of the volatile fraction of these cheeses, produced using milk from the same ewe flock, under the same standardized technological conditions, confirmed that the type of diet was responsible for the presence not only of a marker compound, but 
also of other volatiles, showing differences in the animal metabolism, milk fat oxidation, and microbial development during ripening.

\section{ACKNOWLEDGMENTS}

This work was supported by Interreg IIIa 2001-2006, Livorno province and Corsica region. The authors thank G. Mellerio (Centro Grandi Strumenti, Università di Pavia) and S. Fiorina (ThermoElectron) for their support in the recognition of the unknown compound by chemical ionization mass spectrometry.

\section{REFERENCES}

Acree, T., and H. Arn. 2004. http://www.flavornet.org/flavornet.html Accessed December 2006.

AOAC. 2000. Official Methods of Analysis. Vol. II. 17th ed. Association of Official Analytical Chemists International, Gaithersburg, MD.

Arthur, C. L., and J. Pawliszyn. 1990. Solid phase microextraction with thermal desorption using fused silica optical fibers. Anal. Chem. 62:2145-2148.

Bassette, R., M. E. Turner, and G. Ward. 1966. Volatile compounds in blood, milk, and urine of cows fed silage-grain, bromegrass pasture, and hay-grain test meals. J. Dairy Sci. 49:811-815.

Bendall, J. G. 2001. Aroma compounds of fresh milk from New Zealand cows fed different diets. J. Agric. Food Chem. 49:4825-4832.

Bosset, J. O., U. Bütikofer, R. Gauch, and R. Sieber. 1994. Caractẽrisation de fromages d'alpages subalpins suisses: Mise en évidence par GC/MS de terpènes et d'hydrocarbures aliphatiques lors de l'analyse par $<<$ Purge and Trap $>>$ des arômes volatils de ces fromages. Schweiz Milchw. Forsch. 23:37-41.

Bosset, J. O., M. Gubler, U. Bütikofer, R. Gauch. 2000. Mono-, diand trimethyl benzene in frozen cheese samples: Natural metabolites or environmental pollutants? Mitt. Lebensm. Hyg. 91:287-299.

Buchin, S., B. Martin, D. Dupont, A. Bornard, and C. Achilleos. 1999. Influence of the composition of Alpine highland pasture on the chemical, rheological and sensory properties of cheese. J. Dairy Res. 66:579-588.

Buchin, S., J.-C. Salmon, A.-P. Carnat, T. Berger, C. Bugaud, and J.-O. Bosset. 2002. Identification de composés monoterpéniques, sesquiterpéniques et benzéniques dans un lait d'alpage trés riche en ces substances. Mitt. Lebensm. Hyg. 93:199-216.

Bugaud, C., S. Buchin, J.-B. Coulon, A. Hauwuy, and D. Dupont. 2001a. Influence of the nature of alpine pastures on plasmin activity, fatty acid and volatile compound composition of milk. Lait 81:401-414.

Bugaud, C., S. Buchin, A. Hauwuy, and J.-B. Coulon. 2001b. Relationships between flavour and chemical composition of Abondance cheese derived from different types of pastures. Lait 81:757-773.

Calvo, M. M., and L. de la Hoz. 1992. Flavour of heated milks. A review. Int. Dairy J. 2:69-81.

Carbonell, M., M. Nuñez, and E. Fernández-García. 2002. Evolution of the volatile components of ewe raw milk La Serena cheese during ripening. Correlation with flavour characteristics. Lait 82:683-698.

Christensen, T. C., and G. Holmer. 1996. GC/MS analysis of volatile aroma components in butter during storage in different catering packages. Milchwissenschaft 51:134-138.

Contarini, G., and M. Povolo. 2002. Volatile fraction of milk: Comparison between purge and trap and solid phase microextraction techniques. J. Agric. Food Chem. 50:7350-7355.

Drawert, F., P. Schreier, S. Bhiwapurkar, and I. Heindze. 1981. Chemical-technological aspects for concentrations of plant aromas. Page 649 in Flavour '81. P. Schreier, ed. Walter de Gruyter, Berlin, Germany.
Earley, R. R., and A. P. Hansen. 1982. Effect of process and temperature during storage on ultra-high temperature steam-injected milk. J. Dairy Sci. 65:11-16.

Forina, M., R. Leardi, C. Armanino, and S. Lanteri. 1988. PARVUS: An extendable package of programs for data exploration, classification and correlation. Scientific Software Elsevier, Amsterdam, the Netherlands.

Frankel, E. N. 1980. Lipid oxidation. Prog. Lipid Res. 19:1-22.

Gordon, D. T., and M. E. Morgan. 1972. Principal volatile compounds in feed flavored milk. J. Dairy Sci. 55:905-911.

Jennings, W., and T. Shibamoto. 1980. Qualitative analysis of flavour volatiles by glass capillary gas chromatography. Academic Press, London, UK.

Kataoka, H., H. L. Lord, and J. Pawliszyn. 2000. Applications of solid-phase microextraction in food analysis. J. Chromatogr. A 880:35-62.

Kim, G.-Y., J.-H. Lee, and D. B. Min. 2003. Study of light-induced volatile compounds in goat's milk cheese. J. Agric. Food Chem. 51:1405-1409.

Kim, Y. D., and C. V. Morr. 1996. Dynamic headspace analysis of light activated flavor in milk. Int. Dairy J. 6:185-193.

Larráyoz, P., M. Addis, R. Gauch, and J. O. Bosset. 2001. Comparison of dynamic headspace and simultaneous distillation extraction techniques used for the analysis of the volatile components in three European PDO ewes' milk cheeses. Int. Dairy J. 11:911-926.

Le Quéré, J.-L., A. Pierre, A. Riaublanc, and D. Demaizières. 1998. Characterization of aroma compounds in the volatile fraction of soft goat cheese during ripening. Lait 78:279-290.

Marilley, L., and M. G. Casey. 2004. Flavours of cheese products: Metabolic pathways, analytical tools and identification of producing strains. Int. J. Food Microbiol. 90:139-159.

Marsili, R. T. 1999. Comparison of solid-phase microextraction and dynamic headspace methods for the gas chromatographic-mass spectrometric analysis of light-induced lipid oxidation products in milk. J. Chromatogr. Sci. 37:17-23.

Marsili, R. T. 2000. Shelf-life prediction of processed milk by solidphase microextraction, mass spectrometry, and multivariate analysis. J. Agric. Food Chem. 48:3470-3475.

McLafferty, F., and D. Stauffer. 1988. Wiley Registry of Mass Spectral Data. 4th ed. Wiley and Sons, New York, NY.

McSweeney, P. L. H., and M. J. Sousa. 2000. Biochemical pathways for the production of flavour compounds in cheeses during ripening: A review. Lait 80:293-324.

Moio, L., J. Dekimpe, P. Etievant, and F. Addeo. 1993a. Neutral volatile compounds in the raw milks from different species. J. Dairy Res. 60:199-213.

Moio, L., J. Dekimpe, P. Etievant, and F. Addeo. 1993b. The neutral volatile compounds of water buffalo milk. Ital. J. Food Sci. 1:43-56.

Moio, L., L. Rillo, A. Ledda, and F. Addeo. 1996. Odorous constituents of ovine milk in relationship to diet. J. Dairy Sci. 79:1322-1331.

Palomino, E., C. Maldonado, M. B. Kempff, and M. B. Ksebati. 1996. Caparratriene, as an active sesquiterpene hydrocarbon from Ocotea caparrapi. J. Nat. Prod. 59:77-79.

Povolo, M., and G. Contarini. 2003. Comparison of solid-phase microextraction and purge-and-trap methods for the analysis of the volatile fraction of butter. J. Chromatogr. A. 985:117-125.

Reddy, M. C., R. Bassette, W. George, and J. R. Duhnam. 1967. Relationship of methyl sulfide and flavor score of milk. J. Dairy Sci. 50:147-150.

Schlichtherle-Cerny, H., M. Imhof, E. Fernández-García, and J.-O. Bosset. 2004. Changes in terpene composition from pasture to cheese. Mitt. Lebensm. Hyg. 95:681-688.

Shooter, D., N. Jayatissa, and N. Renner. 1999. Volatile reduced sulphur compounds in butter by solid phase microextraction. J. Dairy Res. 66:115-123.

Spinhirne, J. P., J. A. Koziel, and N. K. Chirase. 2003. Characterizing volatile fatty acids and other gases in a rumen closed in vitro fermentation system using solid phase microextraction. Trans. ASAE 46:585-588. 
Spinhirne, J. P., J. A. Koziel, and N. K. Chirase. 2004. Sampling and analysis of volatile organic compounds in bovine breath by solidphase microextraction and gas chromatography-mass spectrometry. J. Chromatogr. A 1025:63-69.

Vasquez-Landaverde, P. A., G. Velazquez, J. A. Torres, and M. C. Qian. 2005. Quantitative determination of thermally derived offflavor compounds in milk using solid-phase microextraction and gas chromatography. J. Dairy Sci. 88:3764-3772.

Verdier-Metz, I., J.-B. Coulon, P. Pradel, C. Viallon, H. Albouy, and J.-L. Berdagué. 2000. Effect of the botanical composition of hay and casein genetic variants on the chemical and sensory characteristics of ripened Saint-Nectaire type cheeses. Lait 80:361-370.

Viallon, C., B. Martin, I. Verdier-Metz, P. Pradel, J.-P. Garel, J.-B. Coulon, and J.-L. Berdagué. 2000. Transfer of monoterpenes and sesquiterpenes from forages into milk fat. Lait 80:635-641.

Williams, K. I. H., S. H. Burstein, and D. S. Layne. 1966. Dimethylsulfone: Isolation from cow's milk. Proc. Soc. Exp. Biol. Med. 122:865-866.

Yvon, M., and L. Rijnen. 2001. Cheese flavour formation by amino acid catabolism. Int. Dairy J. 11:185-201. 